\title{
ETHNIC-RACIAL RELATIONS: social and cultural values in early Childhood Education
}

RELAÇÕES ÉTNICO-RACIAIS: valores sociais e culturais na Educação Infantil RELACIONES ÉTNICO-RACIALES: valores sociales y culturales en la educación infantil

\section{Nelson Russo de Moraes \\ $\mathrm{PhD}$ in Communication and Contemporary Culture (UFBA). Master in Social Work from UNESP, Graduated in Administration from the Toledo Educational Institution of Bauru / SP. Associate Professor of the Graduate Program in Agribusiness and Development / PGAD / FCE / UNESP / Tupã. nelsonrusso@tupa.unesp.br. \\ 0000-0003-0159-9433}

\section{Celenita Gualberto Pereira Bernieri}

Master in Sustainability and Traditional Peoples (UNB). Graduated in Pedagogy (UNITINS) and Public Administration (UFT). Researcher of Traditional Communities, Culture, Education and Public Management (UNESP and UNB). celecgpb@gmail.com.

\section{0-0001-6437-1538}

\section{Jardilene Gualberto Pereira Fôlha}

Master in Education (UFT), Graduated in Pedagogy (UFT). Researcher of Traditional Communities, Educational Curricula and Children (UNESP and PPGE / UFT).jard-25@hotmail.com.

0000-0001-7216-5232

\section{Laurenita Gualberto Pereira Alves}

Master student in Education-UFT, Graduated in Normal Superior-Unitins. Researcher of Traditional Communities and Children (UNESP and PPGE / UFT). laurinhagualberto25@gmail.com.

\section{0-0002-6009-2416}

Correspondence: Faculdade de Ciências e Engenharia Câmpus de Tupã, Rua Domingos da Costa Lopes,780 Jd. Itaipu - Tupã/SP - CEP 17602-496.

\author{
Received: 10.12.2020. \\ Accepted: 11.20.2020. \\ Published: 01.01.2021.
}

\begin{abstract}
:
Brazilian society is multicultural, formed by several ethnic-racial groups, however, the history of many of these peoples is marked by discrimination and inequality. The reeducation of ethnic-racial relations is not an exclusive responsibility of the school; however, it plays a fundamental role in this struggle. Educational practices that promote the valuation of several cultures and knowledge strengthen ethnic-racial relations in the school context, especially if they are promoted from the first years of the child's life. The article aims to study ethnicracial relations, developed through social and cultural values, which provide significant elements for the development of babies and children. The research points out that educational practices focused on ethnic-racial relations favor to the children moments of experiences on subjects that permeate everyday life, situations that allow internalizing attitudes of respect for everyone, regardless of differences.
\end{abstract}

KEYWORDS Ethnic-Racia Relations; Early Childhood Education; Social and Cultural Aspects.

\section{Introduction}

This work discusses the theme of ethnic-racial relations in Early Childhood Education, starting from the conception that the child's development process happens from significant practices that make sense for their educational, historical, social and cultural context. Relationships and interactions are fundamental for the development of children, and it is through the interactions of children with other children and with adults of different ethnicities, that they learn to live, know and respect the different cultures and knowledge that composes Brazilian diversity. Educational practices that promote the valuation of different cultures and knowledge strengthen ethnic-racial relations in the school context. 
In Brasil (2004) the meaning of the term ethnic-racial relationship determines that the strained racial relations established in the country, go beyond the differences in skin color and physiognomic traits, but also correspond to the cultural root based on AfroBrazilian ancestry that differs in worldview, values and principles of European origin.

Culture, on the other hand, is made up of explicit and implicit elements, Azevedo (1996) describes it as the set of senses and meanings, values and standards, incorporated and underlying the perceptible phenomena of the life of a concrete social group, a group that is consciously or unconsciously experienced and assumed by the group as its own expression of its human reality and passes from generation to generation, preserved as it was received or transformed, effectively or allegedly by the group itself.

Ethnic-racial relations, and consequently cultures, are included in the social and historical-cultural aspects that allow the child to interpret the world from interactions, favoring the development of learning.

In this context, the main objective of this study is, therefore, to study the ethnicracial relations developed through social and cultural values, which provide significant elements for the development of babies and children.

It was used as a methodological resource, bibliographic research with a qualitative approach, based on the analysis of materials already published in the literature and articles. The bibliographic survey and documentary allowed to review and compare the ideas of authors who portray and describe ethnic-racial relations in Early Childhood Education.

Having as its guiding thread anthropological studies related to education for ethnic racial relations, the study is preferably based on the discussions presented based on the thought of Munanga (2008), in which he fights against the Eurocentric vision and demystified racial democracy in Brazil. When dealing with cultural practices Azevedo (1996), Bernieri, Fôlha and Alves (2017); in the mediation of learning and the construction of meanings Libâneo (1996) and Kramer (2008); in debates about the educator's educational intentions in Finco, Barbosa and Faria (2015), Hermida (2007) and Goulart (2010). In addition to legislation such as: the Federal Constitution (1988), Statute of Racial Equality, the Law of Guidelines and Bases of Education (1996), National Plan for the Implementation of the National Curriculum Guidelines for the Education of Ethnic-Racial Relations and for the Teaching of Afro-Brazilian and African History and Culture (2009), Statute of Children and Adolescents and the Common National Curricular Base (2017). 


\title{
Ethnic-racial relationships: significant elements for childhood education
}

Education is the right of the child and the duty of the State, with the 1980 Constitution, made the access to education for children from zero to six years old inalienable, important social achievement and a great step towards the immense Brazilian challenge with regard to Early Childhood Education. Being the first stage of Basic Education, an Early Childhood Education aims to provide babies and children with relevant experiences and experiences with an adequate to develop a child in an integral way.

Finco, Barbosa and Faria (2015), explain that it is essential that Early Childhood Education is a space for comprehensive educational practices.

\begin{abstract}
In the Federal Constitution of 1988 and LDB / 1996, the pedagogical action with children from 0 to 6 years of age received the name of Early Childhood Education with the intention of differing from the term teaching that preceded the Elementary and High School stages. It will be a space that houses comprehensive educational actions, not only of systematized knowledge and organized by areas, but also knowledge derived from social practices, popular cultures, relationships and interactions, encounters that require the constitution of a time and a space of common life in which social and personal experiences can be shared. (FINCO, BARBOSA and FARIA, 2015, p. 187).
\end{abstract}

Developing the child fully means taking social and cultural aspects into account, in the dimensions: "physical, psychological, intellectual and social, complementing the action of the family and the community" (LDB, Art.29). In this perspective, it is essential that educational practices consider the ethnic, religious, gender, social and cultural diversity of Brazilian children, which favors the composition of educational proposals and projects that address the needs of children and families.

Brazilian society is formed by groups and communities of different cultural origins, which makes it a multicultural country, and the relations between different groups can be harmonious, as well as there can be conflicts, due to that, educational practices related to respect of human diversity have been part of the child's life since the early years. Due to the multiculturalism of Brazilian society, "the need arises to promote an education that treats diversity through an intercultural understanding". (BERNIERI, FÔLHA E ALVES, 2017, p. 57).

When observing conflicts due to the multiple ethnicities and cultures existing in Brazilian society, there is an urgent need to work them more systematically in the school environment. Bernieri; Fôlha and Alves (2017), they argue that intolerance, discrimination, racism and racial prejudice are serious problems that permeate society in general, so, the school space is also an environment where this problem is configured. 
In Brazil, historically, the legal aspect has maintained a permissive attitude for many years in the face of discrimination and racism that affects children of different ethnicracial, social and other. When analyzing data from Brazilian surveys that point to inequalities between ethnicities, there is an urgent need to insert educational practices and new teaching methodologies about human diversity since the child's first years of life. The Federal Constitution (1998) states that all are equal before the law, without distinction of any kind. It is a fundamental principle of the Federative Republic of Brazil to promote the common good, without prejudice of origin, race, sex, color, age or any other form of discrimination.

The Child and Adolescent Statute (1991), guarantees the right to freedom, respect and dignity of human persons in the development process, as subjects of civil, human and social rights, as well as the right to education, aiming at the full development of the person, the preparation for the exercise of the equality of condition for the access and permanence in the school; right to be respected by their educators; and having respected the cultural, artistic and historical values inherent in the social context of children and adolescents, guaranteeing them freedom of creation and access to cultural sources.

To strengthen teaching on the culture of the Afro-Brazilian people, the National Plan for the Implementation of the National Curriculum Guidelines for the Education of Ethnic-Racial Relations was approved and for the Teaching of Afro-Brazilian and African History and Culture (2009), the plan agrees that the challenges of quality and equity in education will only be overcome if the school is a welcoming environment that recognizes and values differences and does not turn them into factors of inequality. Guaranteeing the right to learn implies making the school a place where everyone feels valued and recognized as subjects of law in their uniqueness and identity.

The role of Early Childhood Education is significant for human development, personality formation, intelligence building and learning. The collective educational spaces, in the first years of life, are privileged spaces to promote the elimination of any form of prejudice, racism and discrimination, making children, since a very young age, understand and consciously engage in actions that know, recognize and value the importance of different ethnic-racial groups in history and Brazilian culture. (BRASIL, 2009, p. 49).

Educational institutions have a decisive responsibility for strengthening ethnicracial relations, their function goes beyond formal education, it also includes personal and social training. It favors the opportunity to meet other groups of babies and children, so that they can get to know and respect different cultures and ways of life. Allows you to learn about socio-historical, ethnic and cultural values through meaningful experiences 
that make sense to children, and it becomes a positive condition to teach them how to live in society.

The child, according to the National Curriculum Guidelines for Early Childhood Education-DCNEl (2009), it is considered as an active subject and that produces culture.

Historical and rights subject who, in the interactions, relationships and daily practices he experiences, builds his personal and collective identity, plays, imagines, fantasies, wishes, learns, observes, experiences, narrates, questions and builds meanings about nature and society, producing culture. (BRASIL, 2009, p. 12).

The child as a historical and rights subject needs to know, live and explore his culture and the group that is inserted: way of life, cultural baggage, individual interests and of their community, situations that contribute to the construction of personal, social and cultural identity.

The National Common Curricular Base (2017) can be understood as a plural, contemporary document that clearly establishes the set of essential and indispensable learning to which all students are entitled. The BNCC expresses the commitment of the Brazilian State "with the promotion of a comprehensive education aimed at welcoming, recognizing and fully developing all students, with respect to differences and facing discrimination and prejudice". (BRASIL, 2017, p.04)

Based on the legislation, guarantees have been established so that babies and children can play, participate, explore, express and get to know each other through educational experiences and experiences that consider ethnic diversity. However, it appears that the teaching process, adopted by contemporary professionals, has not yet been sufficient to internalize the issue of diversity in a meaningful way in practice. This is because most educators in Brazilian society have not acquired in their education the necessary preparation to work with the challenges that exist in living with diversity and expressions of discrimination. Teachers, parents and students in general are the result of a Eurocentric education, as a result of which, the consciences or prejudices that are in society are reproduced, often consciously or unconsciously.

It is observed that, offering an education for diversity is still a challenge for the State and for education professionals. Among the various difficulties encountered in education and care for children, there is the need to adopt educational practices that take into account Brazilian diversity and achieve positive and significant results. Most educators continue with outdated educational practices, instead of building collective ways, new forms of coexistence and respect between educators, children and the community. (ROCHA \& FÔLHA, 2017, p.34) 
Many schools still work with literature and toys that represent only part of babies and children. It is worth mentioning that, when presenting a character of different ethnicracial, they expose in a stereotyped and caricatural way, deprived of humanity and citizenship. Literatures like these strengthen the practices of disrespect for others and perpetuate the most diverse forms of racism, discrimination and intolerance. When children's literature is used properly, it becomes an important tool in the construction of children's knowledge, and makes them wake up to the world of reading as an act of meaningful learning. Venturini (2017) points out that an essential measure is to acquire teaching materials that value cultural differences, the methodological procedures can be storytelling, making puppets, and it is up to the school to guide its team, in order to develop the philosophical principle of pluralism in thought, of ethical and political content, that it should act as an antidote to the maintenance of reductionist practices that limit,inferiorize and exclude, such as racism.

Both reading and playing, educate and stimulate the development of attention, imagination, observation, memory, reflection and language of babies and children. In this perspective, it is important that educational toys and books represent diversity, which favors children with more inclusive attitudes and the acceptance of differences. For children to identify themselves with dolls of different types, to strengthen their own identity and to value themselves and their neighbors. During play, a child learns to live with social diversity, and consequently, becomes an adult prepared to live in society.

To work on ethnic-racial relations in the classroom, it is necessary to know to understand and respect, it is to accept the collaboration of countless cultures, coming from the diverse cultural matrixes present in society. In this sense, Munanga (2008) states that it is necessary to reflect the extent to which cultures originating from subordinate groups in society, whose contributions are not considered a tradition and a significant past and, therefore, are made invisible and minimized in the curricula, may come to be an object of investigation and constitute the educational practice of teachers. On the other hand, the subjects of these cultures are represented, in large part, in the media and pedagogical materials, in stereotyped and caricatural form, without humanity and citizenship.

For Libâneo (1996), there is no society without educational practice, nor educational practice without society. Educational practice is not only a requirement of life in society, but also the process of providing individuals with cultural knowledge and experiences that enable them to act in the social environment, and to transform it according to the economic, social and political needs of the collectivity. Libâneo (1996) still highlights the influence that educational practice has on individuals and states that: 


\begin{abstract}
Through educational action, the social atmosphere exert influences on individuals and these, by assimilating and creating these influences, they become to be able to establish an active and transformative in relation to the social atmosphere. Such influences are manifested through knowledge, experiences, values, beliefs, ways of acting, techniques and customs accumulated by many generations of individuals and groups, transmitted, assimilated and recreated by new generations (LIBÂNEO, 1996, p.15).
\end{abstract}

When the child starts school life, expands his or her universe, once that contact with other children and educators, who have diverse cultural backgrounds and habits, provides opportunities to learn new games, to know people and spaces and acquire knowledge about different realities. According to Goulart (2010), the first experiences are the ones that most deeply mark the person, and when positive, they tend to reinforce attitudes of self-confidence, cooperation, solidarity and responsibility throughout their lives.

The procedure of the educator is fundamental for babies and children to acquire opportunities for stimulating experiences that make it possible to build your own knowledge, considering your ethnic, religious, economic and social characteristics. BNCC (2017) defend that through experiences children can expand the way they perceive themselves and others, value your identity, respect others and recognize the differences that constitute us as human beings. Emphasizes that in Early Childhood Education, it is necessary to create opportunities for children to come into contact with other social and cultural groups, Emphasizes that in Early Childhood Education, it is necessary to create opportunities for children to come into contact with other social and cultural groups, other ways of life, different attitudes, techniques and rituals of personal and group care, customs, celebrations and narratives.

It is important that ethnic-racial relations are introduced in educational experiences in early childhood education in ludic way, through interactions and games, so that children can understand the contributions of all ethnicities to society.In this perspective, Munanga (2008) describes about the importance of all ethnic groups for the formation of the Brazilian identity, and still points out that overcoming racism and intolerance in the country is an urgent task.

It is indispensable that they reflect in your plenitude the contributions of different ethnic groups to the formation of the Brazilian nation and culture. Ignore these contributions - or not giving them due recognition - is also a form of racial discrimination (...). Overcoming racism still present in our society is imperative. It is a moral necessity and a political task of the first magnitude. And education is one of the decisive areas for us to be victorious in this effort. (MUNANGA, 2008 p.11). 
For educators, to educate, to care and to play with babies and children from 0 to 5 years of age, suppose to define in advance how pedagogical practices will be made and developed, aiming at the inclusion of children and families in a life of citizenship. In the same way Hermida (2007) believes that in order to a content peform the mediation of learning in the construction of meanings, the educator needs to know how children think and appropriate of knowledges, in order to know how to intervene in the sense they can move forward. The same author still affirm that it is essential that the professional has clarity and consciousness about the educational intentions that guide his work, and develop clear proposals on what, when and how to teach, in order to be able to teach and to learn activities in an appropriate and consistent with its objectives, enriching and promoting children's development.

Munanga (1998) believes that teachers' lack of preparation is related to the myth of racial democracy that make a compromise without a doubt the fundamental objective of our mission in the process of training future citizens. And he highlights that "we cannot forget that we are the product of a Eurocentric education and we can, in function of this, consciously or unconsciously reproduce the prejudices that permeate our society" (MUNANGA, 1998, p. 15).

According to Kramer (2011), children as social beings who are, have a history, belong to a social class, establish relationships according to their context of origin, have a language, occupy a geographical space and are valued according to standards family context and their own insertion in that context. They are people, rooted in a social whole that surrounds them, and which imprints standards of authority, language, customs on them. About the educator's posture, Kramer (2011) says that the biggest challenge is a sensitive look and listening, understanding language beyond what is said, understanding meanings of the body and movements, tensions and apprehensions, meanings of crying, laughing , of disputes, demonstrations of affection, anger, sharing.

In this same sense, Libâneo (1996) highlights some important aspects to the teachers, like: to know strategies to teach how to think and to teach how to learn; mediate to students to seek a critical perspective of the contents, attend to cultural diversity and respect differences in the school context.

It is essential that the educational institution develops activities based on educational principles, related to the interests and needs of the child, giving priority to learning through problem solution, educational action linked to life, the encouragement of solidarity and tolerance among children. In this perspective, Finco, Barbosa and Faria (2015) affirm that the teacher, with his view of who is with the child, but also with the knowledge and knowledge, performs the complex educational task of enabling meetings, 
to favour ludic interactions, to build times and spaces for the children's experience, with no guarantee that this will happen.

In this segment, BNCC (2017) alerts the institutions that attend the childhood so that, through dialogue, they can provide practices that contemplate cultural diversity.

(...) in order to enhance children's learning and development, the practice of dialogue and the sharing of responsibilities between the Early Childhood Education institution and the family are essential. In addition, the institution needs to know and work with plural cultures, talking with the cultural wealth / cultural diversity of families and the community. (BRASIL, 2007, p.34).

Munanga (2008) affirm that the school, as an integral part of this society that knows itself to be prejudiced and discriminating, but that recognizes that it is time to change, is committed to this need for change, and needs to be a learning space where the transformations must begin to occur in a planned way and collectivelly by all involved, consciously.

A set of forces needs to be added to achieve the transformations, in this perspective, actors such as the state, organized civil society, educators and the academy are indispensable in the process. In this sense, it is agreed with Lima \& Trindade (2009), who point out the continued education of educators and research focused on the theme as necessary for the healthy development of a multicultural society.

Continuing education and research aimed at Africanities and Afrodescendants need in fact be part of the political concerns of official institution and organized civil society, in order to establish this theme as significant and a primary for the concrete implementation of a Brazilian education for all. (LIMA \& TRINDADE, 2009, p. 35).

In order that public policies foucused at ethnic-racial issues, and consequently the appreciation of social and cultural aspects, are achieved, it is necessary that the entire school crew feels valued and supported, however is still not satisfactory the law obligationess if the State does not provide conditions for professional training for those who are part of the school community and who work directly with children.

It is known that school education, although it is not able to solve itself, however, occupies a prominent place in this fight. Based on the awareness of this reality, we know that our work instruments at school and in the classroom, that is, books and other visual didactic material and audiovisual teaching materials, carry the same addicted content, deprecating and prejudiced in relation to peoples and cultures not from the western 
world. The same prejudices also permeate the daily of students' social relations with each other, and of students with teachers in the school space (MUNANGA, 2008, p. 15).

Education is the main tool for social transformation, so the educator provides conditions for babies and children to develop their dialogical capacity, and know the historical roots that constitute Brazilian culture and build their personal, cultural and social identity.

\section{Considerations}

Finally, it verify that the legislatios that promote ethnic-racial relations have been established, however, the processes of strengthening educational practices in schools are still not sufficient to significantly internalize the issue of multicultural society. The conducive learning space to bring about the transformations expected from society, needs a set of forces articulated by the state, organized civil society, academia and the school community.

The research highlights that educational practices, focused on ethnic-racial relations, favor the babies and children moments of experiences on subjects that permeate quotidian, situations that allow internalizing attitudes of respect for everyone, independently of differences.

The process of developing ethnic-racial relations in Early Childhood Education happens when institutions, together with educators, promote ethical education, focused on respect and harmonious coexistence. It is essential that the school routine offers experiences through which babies and children can to know and value the historically constructed knowledge, the various artistic and cultural manifestations and the diversity of cultural experiences and knowledge. As well as, exercise the dialogue, empathy, conflict resolution and cooperation, so that respect for others can be a constant practice since the child's first years of life.

\section{References}

AZEVEDO, M. Basic ecclesial communities and inculturation of the faith. São Paulo: Loyola, 1996.

BERNIERI, Celenita; FÔLHA, Jardilene; ALVES, Laurenita. Ethnic-Racial Relations and Intercultural in Early Childhood Education. In: II INTERFOR, VII ENFORSUP - UFT, September 12 to 15, 2017, Palmas, TO. Proceedings (online). Available at: <https://docs.uft.edu.br/share/s/3iMMPL_wRISw597jz_UE-w>. Accessed on: August 25, 2020.

BRAZIL. Ministry of Education. National Curriculum Guidelines for the Education of Ethnic-Racial Relations and for the Teaching of Afro-Brazilian and African History and Culture. Brasília: Secad / MEC, 2004. Available at: 
<http://www.acaoeducativa.org.br/fdh/wp-content/uploads/2012/10/DCN-s-

Educacao-das-Relacoes-Etnico-Raciais. pdf> . Accessed on: August 24, 2020.

BRAZIL. Presidency of the Republic. Constitution of the Federative Republic of Brazil: promulgated on October 5, 1988. Brasília, DF. Available at:

<http://www.planalto.gov.br/ccivil_03/constituicao/ConstituicaoCompilado.html>.

Accessed on: August 28, 2020.

. Ministry of Education. Common National Curricular Base. Available at:

$<$ http://basenacionalcomum.mec.gov.br/download-da-bncc $>$. Accessed on

August 30, 2020.

. Ministry of Education. Curricular Guidelines for Early Childhood Education.

Available at: <http://www.planalto.gov.br/ccivil_03/leis/19394.htm>. Accessed on

August 30, 2020.

Ministry of Education. National Education Guidelines and Bases Law No. 9394 of

December 20, 1996. Available at:

<http://www.planalto.gov.br/ccivil_03/leis/19394.htm>. Accessed on: August 26, 2020.

. Law No. 8,069 of July 13, 1990. Statute of Children and Adolescents. Available at: <http://www.planalto.gov.br/ccivil_03/leis/L8069.htm>. Accessed on: August 29, 2020.

BRAZIL. Law No. 12,288 of July 20, 2010. Statute of Racial Equality. Available at $<<$ http://www.planalto.gov.br/ccivil_03/_Ato2007-2010/2010/Lei/L12288.htm>. Accessed on: August 29, 2020.

GOULART, Isabelly. The Importance of Early Childhood Education in the Formation of Critical Citizens / Reflective. Available at <http://pedagogia.com.br/artigos/criticoreflexivo/>. Accessed on: August 27, 2020.

HERMIDA, J. F. (org.) Early childhood education: policies and fundamentals. 1st ed. João Pessoa: UFPB University Publisher, 2007.

FINCO, Daniela; BARBOSA, Maria Carmen; FARIA, Ana Lucia Goulart. Fields of experience in the childhood school: Italian contributions to invent a Brazilian early childhood education curriculum. Campinas, SP: Critical Reading Editions, 2015.

KRAMER, Sonia. The social role of early childhood education (1). 2008. Available at: <http://www.dominiopublico.gov.br/download/texto/mre000082.pdf>. Accessed on: August 27, 2020.

LIMA, Maria Batista; TRINDADE, Azoilda Loretto da. Africanities, curriculum and teacher training: challenges and possibilities. In: MELO, Maros Ribeiro de; LIMA, Maria Batista; LOPES, Edinéia Tavares (Orgs.). Identities and alterities: debates and practices based on school routine. São Cristóvão: Editora UFS, 2009.

LIBÂNEO, José Carlos. Didactics. São Paulo: Cortez, (Collection of the Teacher Training Series). 2008.

MUNANGA, Kabengele (org). Overcoming racism at school. Brasília: MEC / SECAD, 2nd ED. 2008.

MUNANGA, Kabengele. Negritude: Uses and senses. 2ed. SP. Attica 1998.

ROCHA José Damião; FÔLHA, Jardilene. Political participation in the educational practices of diversities and ethnic-racial relations developed in CMEI'S palmenses. In: VI Contemporary seminary of the Graduate Program in Education - UFT, 2017, Palmas, TO. annals (online). Available at: $<$ https://en.scribd.com/document/376272445/Anais-VI-seminario-PPGE-2017-2pdf >. Accessed on: August 26, 2020.

VENTURINI, Andressa. Ethnic-racial relations in early childhood education.

Federal University of Santa Maria, 2015. 


\section{Crevisto Observatório}

RESUMO:

A sociedade brasileira é multicultural, formada por vários grupos étnico-raciais, no entanto, a história de muitos desses povos é marcada por discriminações e desigualdades. A reeducação das relações étnico-raciais não é uma responsabilidade exclusiva da escola, porém, a mesma desenvolve um papel fundamental nessa luta. $\mathrm{O}$ artigo tem como objetivo estudar as relações étnico-raciais, desenvolvidas por meio dos valores sociais e culturais, que proporcionam elementos significativos para o desenvolvimento dos bebês e das crianças. A pesquisa aponta que as práticas educativas voltadas para as relações étnico-raciais favorecem às crianças momentos de vivências e experiências sobre assuntos que permeiam o cotidiano, situações que permitem internalizar atitudes de respeito a todos, independentemente das diferenças.

PALAVRAS-CHAVE: Relações Étnico-Raciais; Educação Infantil; Aspectos Sociais e Culturais.

\section{RESUMEN:}

La sociedad brasileña es multicultural, formada por varios grupos étnico-raciales, sin embargo, la historia de muchos de estos pueblos está marcada por la discriminación y la desigualdad. La reeducación de las relaciones étnico-raciales no es una responsabilidad exclusiva de la escuela, sin embargo, desarrolla un papel fundamental en esta lucha. El artículo pretende estudiar las relaciones étnico-raciales, desarrolladas a través de los valores sociales y culturales, que proporcionan elementos significativos para el desarrollo de los bebés y los niños. La investigación señala que las prácticas educativas centradas en las relaciones étnico-raciales proporcionan a los niños momentos de experiencias sobre temas que impregnan su vida cotidiana, situaciones que les permiten interiorizar actitudes de respeto hacia todos, independientemente de las diferencias.

PALABRAS-CLAVES: Relaciones ÉtnicoRaciales; Educación Infantil; Aspectos Sociales y Culturales. 